\title{
Nematicidal activity of native Bacillus thuringiensis against the root knot nematode, Meloidogyne incognita (Kofoid and White)
}

\author{
A. Ramalakshmi ${ }^{i^{*}}$, R. Sharmila ${ }^{2}$, M. Iniyakumar ${ }^{3}$ and V. Gomathi ${ }^{1}$
}

\begin{abstract}
In this study, potential of the native Bacillus thuringiensis Berliner was investigated against the root knot nematode, Meloidogyne incognita (Kofoid and White) under laboratory and greenhouse conditions. Fourteen out of $50 \mathrm{Bt}$ isolates obtained from root zone of vegetable crops of north western zone of Tamil Nadu, India, were found to be encoded with nematicidal cry genes, confirmed by gene-specific PCR. Nine different Cry protein profiles were obtained from native Bt. Spore-crystal mixtures of 6 isolates out of 14 (at $0.5 \%$ ) showed 100\% inhibition to J2 juveniles emergence from egg masses of $M$. incognita within $72 \mathrm{~h}$ of treatment. Analysis by SEM revealed that fluffy egg masses were observed in untreated samples due to hatching, whereas egg masses were covered by gelatinous matrix, when treated with spore-crystal mixture of nematicidal Bt. Two (BC and BD) of the 6 isolates were selected based on their highest nematicidal activity against $J 2$ of $M$. incognita with $L C_{50}$ values of 0.12 and $0.23 \mu \mathrm{g} / \mathrm{ml}$ of protein. The spore-crystal mixtures of isolates $\mathrm{BC}$ and $\mathrm{BD}$ when applied to tomato plants under greenhouse conditions exhibited the enhanced biocontrol potential by suppressing number of egg masses, reduction of female population and decreased root gall index, when compared to control and chemical treatments.
\end{abstract}

Keywords: Bacillus thuringiensis, nematicidal cry genes, Meloidogyne incognita, Biological control

\section{Background}

Meloidogyne spp. are the most devastating plant-parasitic nematodes (PPNs) causing serious economic damage to agricultural and horticultural crops. The genus has 98 species among which $M$. incognita causes root galls in almost all vascular plants (Jones et al. 2013). Meloidogyne spp. are very difficult to control owing to their quick generation time, high reproduction rate, entophytic and sedentary nature (Engelbrecht et al. 2018).

The uses of chemical nematicides are under scrutiny now because of growing awareness of their harmful effects on soil, water, environment and non-targeted

\footnotetext{
* Correspondence: ramalakshmia@gmail.com

'Department of Agricultural Microbiology, Tamil Nadu Agricultural University, Coimbatore, Tamil Nadu 641003, India

Full list of author information is available at the end of the article
}

organisms. Besides, Meloidogyne spp. have developed resistance to many of these nematicides. Hence, there is a lot of emphasis on finding a sustainable alternative to chemical nematicides for the control of Meloidogyne spp.

Biological control as an environmental friendly alternative in integrated pest management strategy is gaining momentum recently (Pocurull et al. 2020; Radwan et al. 2012; Siddiqui and Futai 2009). Bacillus thuringiensis $(B t)$, a gram positive soil bacterium possessing nematicidal crystal proteins, is being used widely to control PPNs. For instance, BtCR371 was evaluated and found effective against a model nematode, Caenorhabditis elegans under in vitro and in vivo conditions (Zuckerman and Dicklow, 1993). Mohammed et al. (2008) studied the biocontrol efficacy of $B t$ against $M$. incognita and 
observed a reduction of egg masses and number of eggs over untreated samples. BtDB27 produced 2 novel protoxins namely, Cry21Fa1 and Cry21Ha1, which exhibited synergistic action towards Caenorhabditis elegans (Iatsenko et al. 2014). Scientists also explained the mechanism of nematode control by Cry proteins. The crystal proteins of different molecular weights are known to enter via stylet of nematodes, cause pores in the esophagus and thereby kill them. Naturally isolated $B t$ often acts as an effective location-specific control agent. The reason might be the bacterium and the nematode might coevolved in that particular ecosystem. The toxicity of location-specific $B t$ is always found to be effective and more novel proteins can be expected out of them.

North western zone of Tamil Nadu, India, one of the highly vegetable growing regions of the nation, with severe nematode infestation, was selected for the present study where the crop yield losses due to $M$. incognita were more than $60 \%$.

In this study, native $B t$ was isolated to control $M$. incognita. The efficacy of spore-crystal mixture (SCM) of the native $B t$ isolates was evaluated under lab and greenhouse conditions.

\section{Materials and methods}

Isolation, screening and identification of Bacillus thuringiensis

The $B t$ was isolated from 5 soil samples collected from each of the 15 different blocks of the north western zone of Tamil Nadu state, India, and stained with Coomassie Brilliant Blue (CBB) (0.133\% CBB in acetic acid 50\%) for identification of crystal morphology as described by (Ramalakshmi and Udayasuriyan 2010). Twenty-four hours old broth culture of crystal positive isolates were prepared as glycerol stocks and stored at $-70{ }^{\circ} \mathrm{C}$ for further studies. Molecular identification, using 16SrRNA gene amplification by PCR was performed to identify the crystal positive isolates. The phylogenetic relationships of isolates are given in Fig. (S3).

\section{Preparation of spore-crystal mixtures (SCM) and SDS- PAGE}

The spore-crystal mixtures were prepared from $B t$ isolates as described earlier (Ramalakshmi and Udayasuriyan 2010). Five microlitres of SCM were analysed by sodium dodecyl sulphate-polyacrylamide gel electrophoresis (SDS-PAGE) (Laemmli 1970).

\section{Screening for nematicidal cry genes by PCR}

The total genomic DNA from $B t$ isolates was extracted, using appropriate methods (Sambrook and Russell 2001). The nematode-specific cry gene primers were used to identify the cry5, cry6, cry 14 and cry21 gene families in $B t$ isolates (Porcar and Juárez-Pérez 2003).
The $25 \mu \mathrm{l}$ PCR reaction mixture consisted of 1X Taq buffer, $2.5 \mathrm{mM} \mathrm{MgCl} 2,0.5 \mu \mathrm{M}$ forward and reverse primers, $0.25 \mathrm{mM}$ dNTP mixtures and $3 \mathrm{U}$ of Taq polymerase (all from Fermentas, USA). PCR condition includes $95^{\circ} \mathrm{C}$ for $5 \mathrm{~min}$ (initial denaturation), 35 cycles of $95^{\circ} \mathrm{C}$ for $1 \mathrm{~min}$ (denaturation), $55^{\circ} \mathrm{C}$ for $1 \mathrm{~min}$ (annealing), $72^{\circ} \mathrm{C}$ for $1 \mathrm{~min}$ (primer extension), followed by $72{ }^{\circ} \mathrm{C}$ for $10 \mathrm{~min}$ (final extension). Amplification was performed in Biorad T100 PCR. Four reference strains of Bt, 4 M1, 4Q1, 4E1 and 4BG1 obtained from Bacillus Genetic Stock Centre (BGSC), the Ohio State University, Columbus, Ohio 43210, were used as a positive control for screening of native $B t$ isolates by PCR.

\section{Root knot nematode and maintenance of egg masses}

The egg masses of root knot nematode (RKN), $M$. incognita were obtained from the Department of Nematology, TNAU, Coimbatore, and maintained in pots having tomato plants.

\section{In vitro inhibition of $M$. incognita egg masses by SCM of Bacillus thuringiensis}

The $B t$ isolates were grown in $\mathrm{T}_{3}$ broth till more than 95\% cell lysis. After lysis, the different crystal protein suspensions $0.1,0.2,0.3,0.4$ and $0.5 \%$ with sterile water were prepared. The egg masses were collected from the pot culture experiment and washed with sterile distilled water before exposure to the crystal protein suspension. Three egg masses were released into each concentration of suspension in $6 \mathrm{~mm}$ dia petriplates. The sterile water with egg masses was used as control. The number of hatched $\mathrm{J}_{2}$ was recorded every $24 \mathrm{~h}$ up to 3 days under binocular light microscope (model Olympus); the images were recorded in Cannon camera $20 \mathrm{MP}$ colour CMOS attached to the Olympus microscope. All the treatments were carried out with three replications.

\section{Scanning electron microscope analysis}

The virulence of $B t$ isolates against $M$. incognita egg masses was confirmed by SEM analysis. The unhatched egg masses of $M$. incognita were observed under SEM after 3 days incubation with different concentrations of SCM of $B t$ isolates, reference strains and control. Sample preparation was made by the modified method (Orion et al. 1994; Wergin and Orion 1981). Briefly, the egg samples were fixed at $4{ }^{\circ} \mathrm{C}$ in closed tubes containing $1.25 \%$ glutaraldehyde and $1.25 \%$ paraformaldehyde in $0.05 \mathrm{M}$ cacodylate buffer ( $\mathrm{pH} 7.2$ ) for $4 \mathrm{~h}$. The samples were treated serially for 15 min with 50, 70, 90 and 100\% ethanol, and butanol. Then the samples are vacuum freeze-dried for $24 \mathrm{~h}$. The samples were coated by carbon grid with platinum coating observed under a SEMFEI-Quanta 250. 


\section{In vitro inhibition of $J_{2}$ juveniles by SCM of Bacillus thuringiensis}

The spore-crystal mixtures from nematicidal positive $B t$ isolates were further tested against $M$. incognita (J2) stage. Known concentration of $5 \mu \mathrm{g} / \mathrm{ml}$ of SCM was transferred into glass plates containing 100 nos of surface sterilised infective juveniles (J2). Four replications of each treatment were made to assess the juvenile mortality. The dead juveniles were counted from each treatment up to $48 \mathrm{~h}$. Juveniles not showed any movement upon addition of water were considered as dead ones. Juveniles released in sterile water served as control. The experiments were performed at $30 \pm 0.5^{\circ} \mathrm{C}$.

\section{Greenhouse experiment}

A pot culture experiment was conducted under greenhouse conditions for testing the biocontrol efficacy of $B t$ against $M$. incognita. Sterilised cocopeat mixture obtained from Orchard, TNAU, Coimbatore, was prepared and filled in 96 well portrays. Tomato seeds (PKM 2 variety obtained from $\mathrm{HC}$ and RI, TNAU, Coimbatore) were planted in portrays and maintained for better establishment. Tomato seedlings after 25 days were transferred to earthen pots of $10 \mathrm{~kg}$ capacity which were filled by steam sterilised pot mixture. M. incognita was inoculated at $1 \mathrm{~J} 2 / \mathrm{g}$ of soil around the roots of tomato plants by making 3 holes around the plant and covered with sterilised soil. Ten millilitres of spore-crystal mixture of isolates $\mathrm{BC}$ and $\mathrm{BD}$ along with reference strain (4 M1) were applied near root zone. As a standard check Carbofuran 3G at $1 \mathrm{~kg}$ a.i/ha and an untreated control were included. Regular watering was done with tap water passed through 325 mesh sieve. The experiment consisted of 4 treatments with 3 replications in a completely randomised block design. Pots were placed at room temperature of $35 \pm 2{ }^{\circ} \mathrm{C}$ under controlled conditions in the greenhouse.

Observations on shoot and root length, shoot and root weight were recorded after 60 days of planting. Plants were carefully uprooted and observation on gall index, number of females, number of egg masses and number of eggs per egg mass were observed. Population of nematode in soil was assessed by (KOPPENHõFER et al. 1998; Schindler 1961).

\section{Statistical analysis}

Data were pooled and analysed in the SPSS 16 software. Duncan's multiple range tests were performed for treatment with spore-crystal mixture. The $P$ value $<0.005$ was kept as cutoff value for significance. The $\mathrm{LC}_{50}$ values were determined by probit analysis using SAS 8.0.

\section{Results and discussion}

Screening of nematicidal $B t$ against $M$. incognita

Fifty native isolates were identified as $B t$ based on the presence of crystalline inclusions. The types of crystalline inclusion present in 50 isolates are presented in fig. (S1). All the 50 isolates were subjected to PCR for confirmation of nematicidal cry genes, using specific primers and simultaneously the spore-crystal mixtures of all the 50 isolates were run on SDS-PAGE to identify the molecular weight of the $c r y$ protein. Crystal protein profiles of 50 isolates were depicted in Fig. (S2). Out of 50 isolates, 14 harboured nematicidal genes and showed amplification of expected size of cry5, cry6, cry 14 and cry 21 genes either in combination or alone (Fig. 1 and Table 1). All the 14 isolates showed variation in their molecular weight of the protein (Table 1 and Fig. 2).

Biological control of insect's pests is known to be very old practice (Laznik et al. 2012). Several studies were attempted on Bacillus sp. based nematode control. However, Bt possessing nematicidal cry genes are more efficient in controlling specific nematodes when compared to Bacillus sp. Moreover, native isolates of $B t$ might harbour novel cry genes for nematode management. Furthermore, studies pertaining to Bt-based nematode control are limited. Iatsenko et al. 2014 extracted 2 novel protoxins viz., Cry21Fa1 and Cry21Ha1, from native $B t$ against $C$. elegans. Similarly, the native $B t$ BRC-XQ12 harbouring CryEa11 was active against pine wood needle nematode, Bursaphelenchus xylophilus (Huang et al. 2018). Guo and co-workers (2008) reported that most of the nematicidal Cry proteins are large proteins (90 to $140 \mathrm{kDa}$ ), except Cry6 (Guo et al. 2008). In the present study, $43-135 \mathrm{kDa}$ proteins in native $B t$ isolates were reported. The two $B t$ isolates shared the same cry 5 amplification profile with $\sim 130 \mathrm{kDa}$ protein and had the highest nematicidal activity against pinewood nematode (Wang et al. 2012). The same result was noticed in the present study also.

Fourteen isolates harbouring nematicidal cry genes were screened by bioassay against egg masses and 2nd stage juveniles (J2) of $M$. incognita for identification of potential isolate. The result revealed that 6 isolates were effective in inhibiting the emergence of $\mathrm{J} 2$ juveniles from egg masses of M. Incognita (Figs. 3 and 4). All the 6 isolates at $0.5 \%$ of SCM inhibited the emergence of $\mathrm{J} 2$ juveniles by $100 \%$. Inhibition percentage of $80-90 \%$ of $\mathrm{J} 2$ juvenile emergence was observed at $0.3-0.4 \%$ SCM of all isolates (Fig. 4). The lowest inhibition was noticed in the concentration of $0.1-0.2 \%$ among the isolates. Microscopic images confirmed the inhibition of emergence of J2 by spore-crystal mixture of native isolates of $B t$ when compared to control (Fig. 3.)

Similarly, mortality of J2 was observed under microscope and the results are presented in Fig. 5. It was 

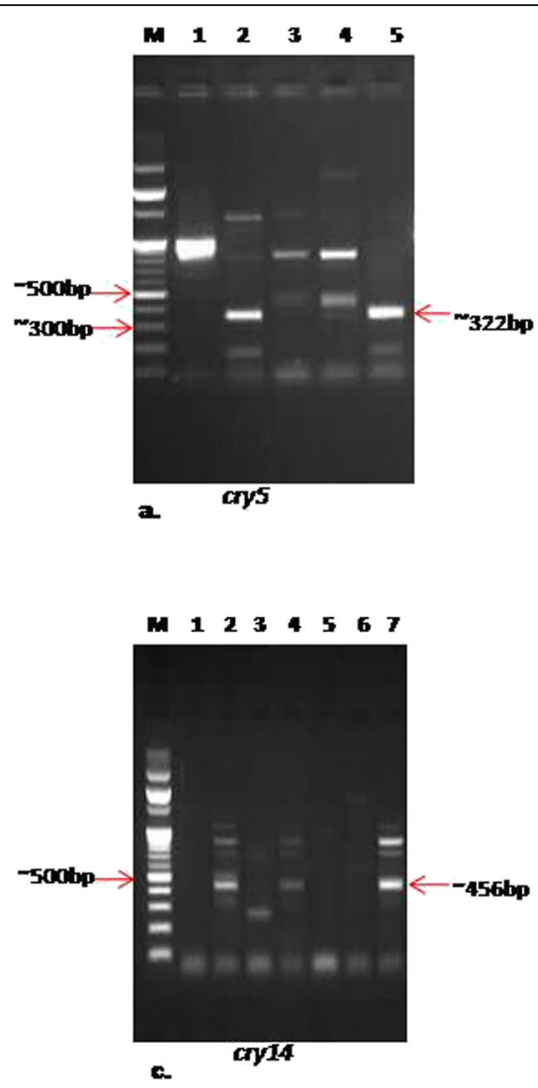

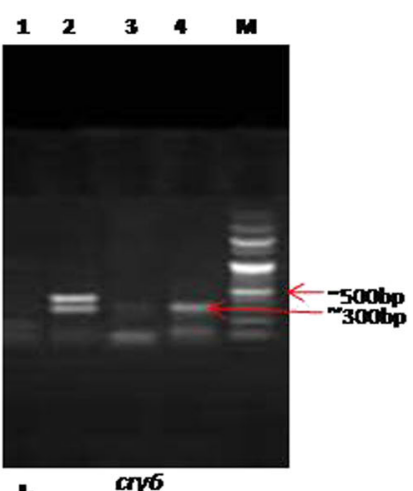

b.

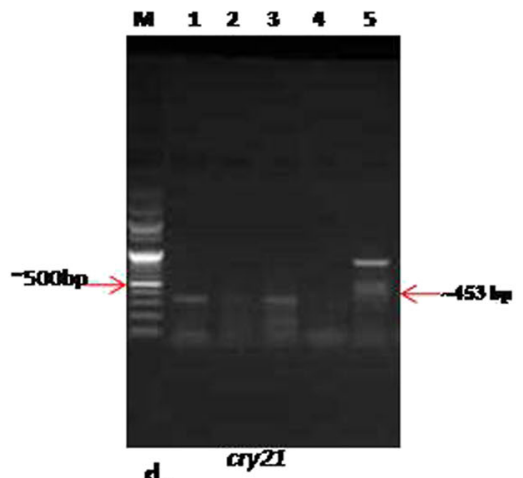

d.

Fig. 1 PCR screening of nematicidal genes in native Bacillus thuringiensis isolates. a cry5at 322 bp ( $\mathrm{M}$, marker; lanes 1 to 5 , native $B t$ isolates), b cry6 at 302 bp (M, marker; lanes 1 to 4, native Bt isolates), c cry 14 at 456 bp (M, marker; lanes 1 to 7, native Bt isolates), d cry21 at 453 bp (M, marker; lanes 1 to 5 , native Bt isolates)

Table 1 Nematicidal cry gene profiles and molecular weight of crystal proteins of native isolates of Bacillus thuringiensis

\begin{tabular}{llll}
\hline No & Bt isolates & Molecular weight of crystal protein(s) (kDa) & Cry gene \\
\hline 1 & B7 & $\sim 135$ & cry5 and cry6 \\
2 & BC & $\sim 135$ & cry5 \\
3 & BB & $\sim 135$ and $\sim 95$ & cry5, cry6 and cry21 \\
4 & CB2 & cry5, cry6, cry14 and cry21 \\
5 & CA & $\sim 135$ and $\sim 65$ & cry5 \\
6 & TE2 & $\sim 135$ & cry5 \\
7 & CE & $\sim 135$ & cry5 and cry6 \\
8 & TE1 & $\sim 135$ & cry5 \\
9 & BD & cry5 \\
10 & TC & $\sim 95$ & cry6 and cry14 \\
11 & Ba1 & $\sim 135$ & cry6 \\
12 & CD & $\sim 95$ and & cry14 \\
13 & CB2 & $\sim 95$ & cry14 \\
14 & BA & $\sim 43$ & cry21 \\
\hline
\end{tabular}




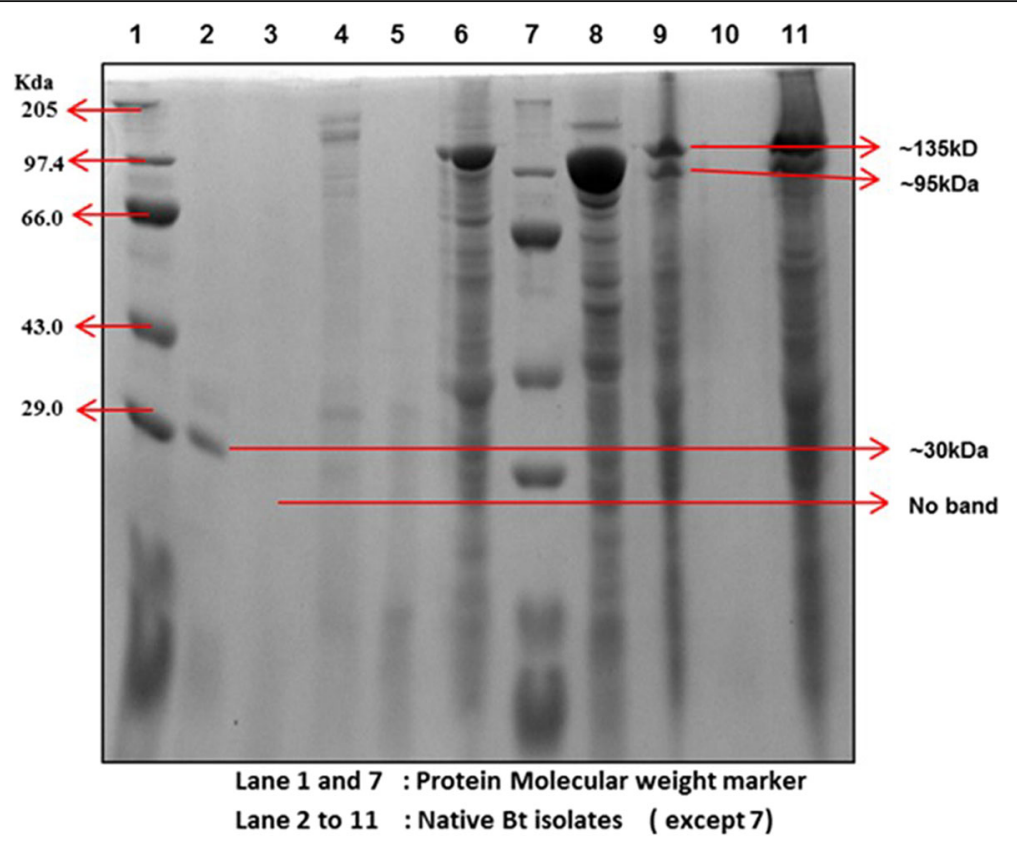

Fig. 2 Cry protein molecular weight variations among native isolates of Bacillus thuringiensis

evident from the figure that the spore-crystal mixturetreated juveniles were dead observed as straight ones, and no movement were noticed even after disturbance with the needle, whereas untreated $\mathrm{J} 2$ were found live by their curved and comma-shaped movement. (Fig. 5).

\section{SEM analysis of changes in egg structure}

The SEM analysis of egg mass treated with SCM of native isolates of $B t$ showed that the eggs were embedded in a gelatinous matrix with smooth egg shells, whereas the egg shells were fluffy owing to hatching in untreated samples (Fig. 5). From the SEM results, it is evident that the proteins inhibited the emergence of $\mathrm{J} 2$ from egg masses.

\section{$\mathrm{LC}_{50}$ value}

The spore-crystal mixture of 6 isolates were further analysed on $\mathrm{J} 2$ of $M$. incognita and $\mathrm{LC}_{50}$ values were found out. The result revealed that lethal concentration varied from 0.12 to $0.23 \mu \mathrm{g}$ of protein (Fig. 6). The isolate $\mathrm{BC}$ recorded lowest $\mathrm{LC}_{50}$ value of $0.12 \mu \mathrm{g}$ of protein/millilitre, followed by the isolate $\mathrm{BD}(0.13 \mu \mathrm{g}$ of protein/millilitre). The highest $\mathrm{LC}_{50}$ value of $0.23 \mathrm{mg}$ of protein/millilitre was recorded in isolate CD2 (Fig. 6). The 2 isolates with low $\mathrm{LC}_{50}$ values, namely $\mathrm{BD}$ and $\mathrm{BC}$, were selected for greenhouse experiment using host plants. The $\mathrm{LC}_{50}$ value obtained in this study was much lower than already reported $\mathrm{Cry} 5 \mathrm{Ba}$ protein whose $\mathrm{LC}_{50}$ value was $146.05 \mu \mathrm{g}$ of protein/millilitre (Peng et al.,

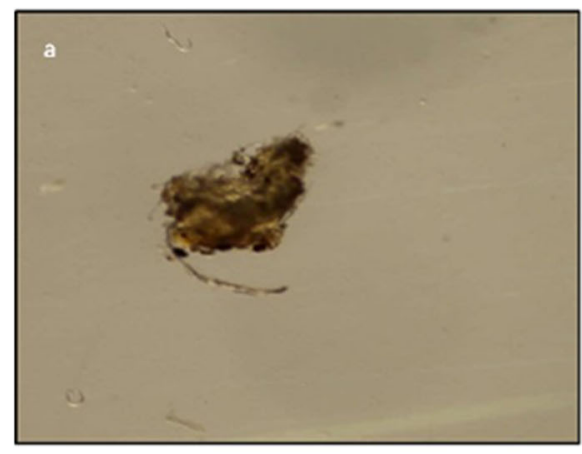

$M$. incognito egg masses treated with spore crystal mixture of $B$ t isolates

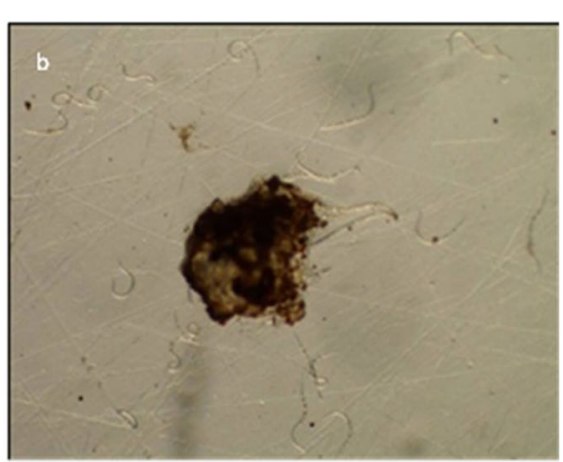

$M$. incognito egg masses untreated

Fig. 3 In vitro inhibition of emergence of J2 juveniles from egg masses of Meloidogyne incognita by spore-crystal mixture of native Bacillus thuringiensis isolates. a Unhatched egg masses of $M$. incognita treated with spore-crystal mixture. b Release of J2 juveniles in untreated egg masses of $M$. incognita 

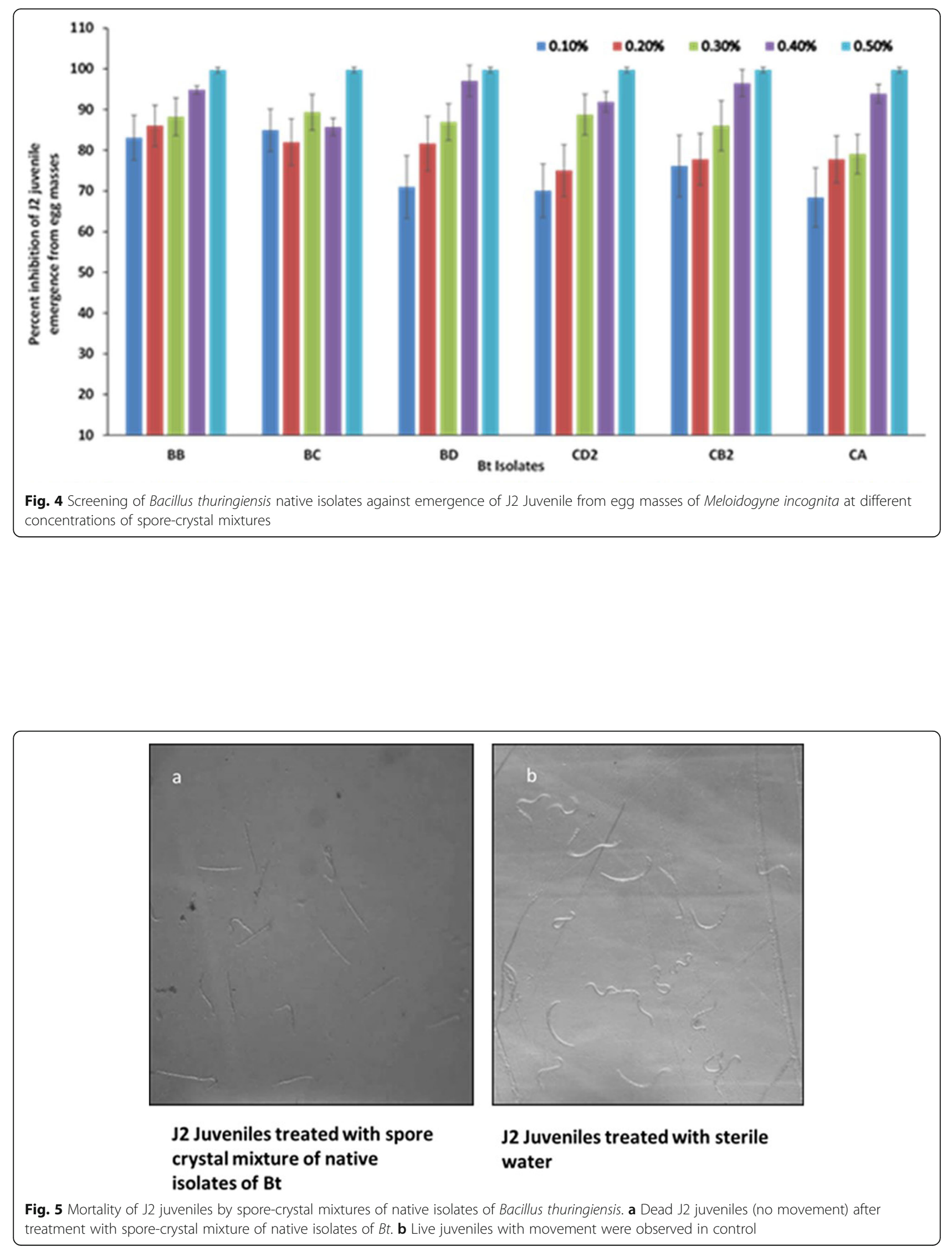


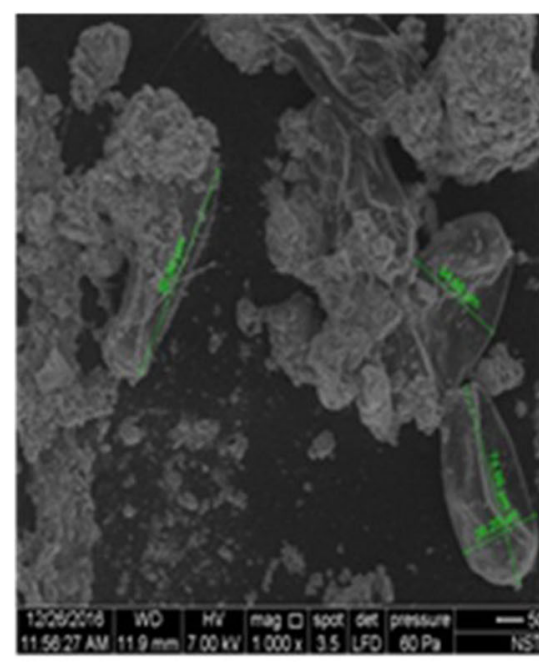

a Untreated Egg Masses

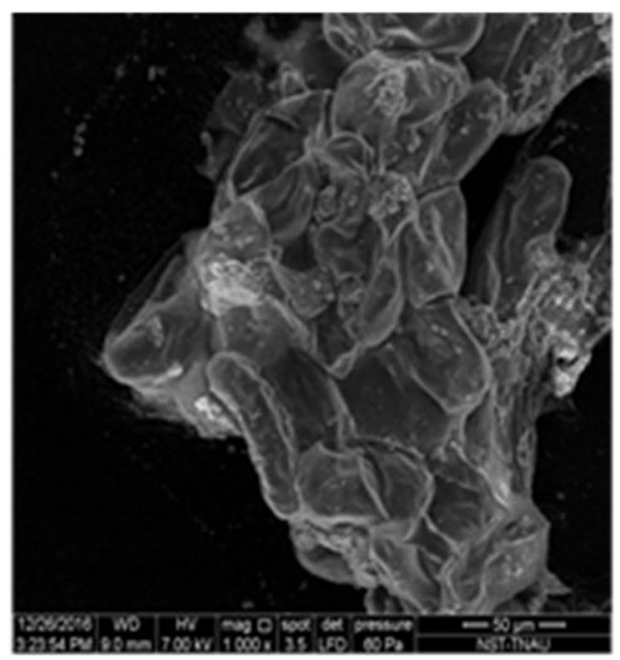

b Egg Masses treated with native isolates of Bacillus thuringiensis

Fig. 6 SEM analysis of changes in egg masses treated with spore-crystal mixture of native isolates of Bacillus thuringiensis. a Untreated egg mass. b Egg mass treated with spore-crystal mixture. c Inhibition of hatching of egg masses by spore-crystal mixture

2011) (Fig. 7). Similarly, the $\mathrm{LC}_{50}$ value of this study could be compared to Huang et al. (2018) where in purified Cry1Ea11 had $\mathrm{LC}_{50}$ of 32.53 and $23.23 \mu \mathrm{g}$ of protein/millilitre after 24 and $48 \mathrm{~h}$, respectively.

\section{Greenhouse experiments}

Biocontrol potential of the 2 native $B t$ isolates ( $\mathrm{BC}$ and $\mathrm{BD})$ was evaluated for their effective control of root knot nematode under greenhouse conditions. The results were compared by chemical nematicide, carbofuran and with reference strain 4MI harbouring cry5 nematicidal gene. Parameters such as number of egg masses $/ 5 \mathrm{~g}$ root, number of eggs/egg mass, number of adult females $/ 5 \mathrm{~g}$ root, final nematode population/kilogram soil and root

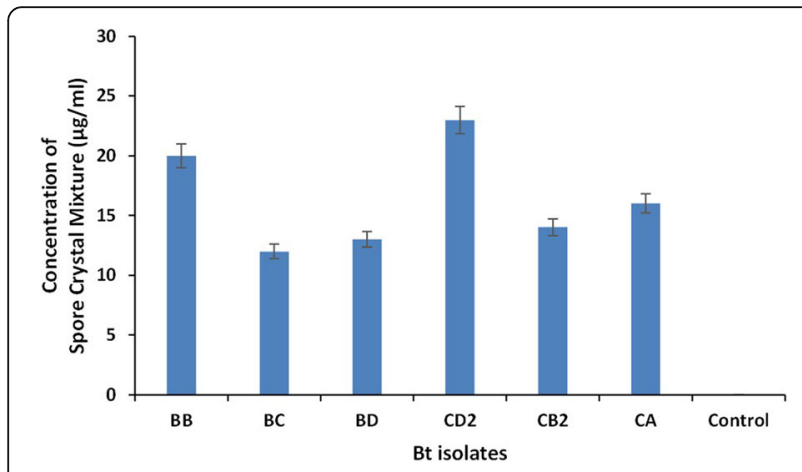

Fig. $7 L C_{50}$ values of spore-crystal mixtures of Bacillus thuringiensis isolates against $\mathrm{J} 2$ juveniles of Meloidogyne incognita under in vitro conditions gall index were evaluated. As shown in Table 2, the 2 native $B t$ isolates exhibited superior biocontrol potential of root knot nematode over the reference strain and chemical control. The highest percent decreased of the number of egg masses per $5 \mathrm{~g}$ of root was observed for the isolate $\mathrm{BC}$ to a tune of 79.35 , followed by $\mathrm{BD}$ (76.09\%). The percent decrease of reference strain 4MI was 66.66 and the lowest percent decrease of egg masses was noticed in the treatment with carbofuran with a value of 31.50 .

Similarly, the results on number of female population per $5 \mathrm{~g}$ of root also followed the same trend. The highest percent reduction of number of female population per 5 $\mathrm{g}$ of root was observed for isolate BC (68.14), followed by the isolate $\mathrm{BD}$ with a percent reduction of 64.53 . The percent reduction of reference strain $4 \mathrm{MI}$ was $52.72 \%$. Reduction percent of 25.45 was observed for treatment with chemicals. Final nematode population per kilogram of soil was estimated and the isolate BD had the lowest number nematode population with $73.15 \%$ decreased over control, followed by isolate BC, which had percent decrease of $71.96 \%$. The lowest values of percent reduction (40.92) in final nematode population were recorded at the treatment with carbofuran. Root gall index was found to be low (1.66) in the native isolates of $B t$ and high of 3.33 was noticed in reference strain $4 \mathrm{MI}$ and in treatment with carbofuran. Bio efficacy of cry6 proteins on nematode $M$. hapla in pot culture experiments with tomato host plant was evaluated by Yu et al. (2015). The results indicated that egg masses were reduced to 62.3 
Table 2 Biocontrol potential of native Bacillus thuringiensis against root knot nematode Meloidogyne incognita in tomato

\begin{tabular}{|c|c|c|c|c|c|c|c|c|c|c|}
\hline Treatments & $\begin{array}{l}\text { No. of egg } \\
\text { masses } / 5 \mathrm{~g} \\
\text { root }\end{array}$ & \%decrease & $\begin{array}{l}\text { No. of } \\
\text { eggs/egg } \\
\text { mass }\end{array}$ & \%decrease & $\begin{array}{l}\text { No. of adult } \\
\text { females } / 5 \mathrm{~g} \\
\text { root }\end{array}$ & $\begin{array}{l}\% \\
\text { decrease }\end{array}$ & $\begin{array}{l}\text { Final nematode } \\
\text { population/ } \\
\text { kilogram soil }\end{array}$ & $\begin{array}{l}\% \\
\text { decrease }\end{array}$ & $\begin{array}{l}\text { Root } \\
\text { gall } \\
\text { index }\end{array}$ & $\begin{array}{l}\% \\
\text { reduction }\end{array}$ \\
\hline Isolate BD & $7.33 \pm 2.15$ & $\begin{array}{l}76.09 \pm \\
9.85\end{array}$ & $\begin{array}{l}140.00 \pm \\
11.25\end{array}$ & $\begin{array}{l}48.40 \pm \\
5.42\end{array}$ & $13.00 \pm 2.53$ & $\begin{array}{l}64.53 \pm \\
15.28\end{array}$ & $143.00 \pm 12.36$ & $\begin{array}{l}73.15 \pm \\
8.56\end{array}$ & $\begin{array}{l}1.66 \pm \\
0.25\end{array}$ & $\begin{array}{l}61.66 \pm \\
13.25\end{array}$ \\
\hline Isolate BC & $6.33 \pm 1.78$ & $\begin{array}{l}79.35 \pm \\
12.36\end{array}$ & $\begin{array}{l}135.66 \pm \\
13.25\end{array}$ & $\begin{array}{l}50.00 \pm \\
6.25\end{array}$ & $11.66 \pm 1.78$ & $\begin{array}{l}68.14 \pm \\
16.56\end{array}$ & $149.33 \pm 13.68$ & $\begin{array}{l}71.96 \pm \\
13.36\end{array}$ & $\begin{array}{l}1.66 \pm \\
0.25\end{array}$ & $\begin{array}{l}61.66 \pm \\
12.36\end{array}$ \\
\hline $\begin{array}{l}\text { Reference strain } 4 \\
\text { M1 }\end{array}$ & $10.22 \pm 3.38$ & $\begin{array}{l}66.66 \pm \\
17.36\end{array}$ & $\begin{array}{l}152.33 \pm \\
15.66\end{array}$ & $\begin{array}{l}43.85 \pm \\
6.32\end{array}$ & $17.33 \pm 3.52$ & $\begin{array}{l}52.72 \pm \\
11.56\end{array}$ & $165.33 \pm 16.68$ & $\begin{array}{l}68.96 \pm \\
15.23\end{array}$ & $\begin{array}{l}3.00 \pm \\
0.35\end{array}$ & $\begin{array}{l}30.71 \pm \\
4.85\end{array}$ \\
\hline $\begin{array}{l}\text { Soil application of } \\
\text { Carbofuran at } 1 \mathrm{~kg} \\
\text { a.i/ha }\end{array}$ & $21.00 \pm 5.20$ & $\begin{array}{l}31.50 \pm \\
4.32\end{array}$ & $\begin{array}{l}218.33 \pm \\
20.63\end{array}$ & $\begin{array}{l}19.53 \pm \\
3.25\end{array}$ & $27.33 \pm 4.56$ & $\begin{array}{l}25.45 \pm \\
6.85\end{array}$ & $314.67 \pm 25.63$ & $\begin{array}{l}40.92 \pm \\
23.56\end{array}$ & $\begin{array}{l}3.00 \pm \\
0.35\end{array}$ & $\begin{array}{l}30.71 \pm \\
4.85\end{array}$ \\
\hline Control & $30.66 \pm 6.82$ & 0 & $\begin{array}{l}271.33 \pm \\
25.65\end{array}$ & 0 & $36.66 \pm 6.25$ & 0 & $532.66 \pm 35.68$ & 0 & $\begin{array}{l}4.33 \pm \\
0.56\end{array}$ & 0 \\
\hline
\end{tabular}

and $67.3 \%$ over control. The final population of nematode in soil was by 52.4 and $59.5 \%$ and the gall index values were reduced by 46.7 and $66.7 \%$.

\section{Conclusion}

The present study demonstrated biocontrol efficiency of 2 native isolates of $B t$ for efficient control of root knot nematode. The study also investigated the changes in egg mass treated with spore-crystal mixture of native isolates of $B t$ by SEM analysis. The $\mathrm{LC}_{50}$ values of the 2 native isolates were much lower than other isolates. Molecular weight of $135 \mathrm{kDa}$ and nematicidal cry 5 gene(s) were noticed in these isolates. Pot culture experiment showed that the 2 isolates were better than reference strain and chemical in controlling egg mass, nematode population and root gall index of tomato plants. The crystal proteins of native isolates of $B t, \mathrm{BC}$ and $\mathrm{BD}$, could be potential candidates for a biocontrol agents in controlling root knot nematode.

\section{Supplementary information}

Supplementary information accompanies this paper at https://doi.org/10. 1186/s41938-020-00293-2.

Additional file 1: Fig. S1. Types of crystalline inclusions in native isolates of $B$. thuringiensis. Fig. S2. Crystal protein profiles of native isolates of $B$. thuringiensis. Fig. S3. Phylogenetic relationship of native isolates of Bacillus thuringiensis

\section{Abbreviations}

PCR: Polymerase chain reaction; SEM: Scanning electron microscope; PPNs: Plant-parasitic nematodes; Bt: Bacillus thuringiensis; SCM: Spore-crystal mixture; $L_{50}$ : Lethal concentration 50; CBB: Coomassie Brilliant Blue; 16srRNA: 16 s ribosomal RNA; SDS-PAGE: Sodium dodecyl sulphatepolyacrylamide gel electrophoresis; RKN: Root knot nematode; TNAU: Tamil Nadu Agricultural University; J2: Second stage juvenile; BGSC: Bacillus Genetic Stock Centre; BC and BD: Name of the Bt isolates

\section{Acknowledgements}

The authors thank Professor and Head, Department of Nano Science and Technology, Tamil Nadu Agricultural University, Coimbatore-641003, for offering scanning electron microscope facility.

\section{Authors' contributions}

All authors read and approved the final manuscript. Dr. A. Ramalakshmi: conceived the idea, proposed the work and designed and wrote the manuscript. Dr. R. Sharmila: conducted the experiments and assisted manuscript preparation. Dr. M. Iniyakumar: contributed SEM analysis and reviewed manuscript. Dr. V. Gomathi: overall supervision and critical suggestion on the manuscript

\section{Funding}

This research work was supported by grant given to A. Ramalakshmi from Department of Science and Technology (SERB), New Delhi, (Sanction order No. SB/YS/LS-274/2013 dt.16.05.2014, by Scientist-'D', SERB, DST, Govt. of India, New Delhi).

\section{Availability of data and materials}

All data analysed in this study are available from corresponding author

\section{Ethics approval and consent to participate}

Not applicable.

\section{Consent for publication}

Not applicable

\section{Competing interests}

The authors declare that they have no competing interests.

\section{Author details}

${ }^{1}$ Department of Agricultural Microbiology, Tamil Nadu Agricultural University, Coimbatore, Tamil Nadu 641003, India. ${ }^{2}$ Department of Nematology, Tamil Nadu Agricultural University, Coimbatore, Tamil Nadu 641003, India.

${ }^{3}$ Department of Crop Management, Kumaraguru Institute of Agriculture,

Nachimuthupuram, Erode, Tamil Nadu, India.

Received: 21 April 2020 Accepted: 30 June 2020

Published online: 08 July 2020

\section{References}

Engelbrecht G, Horak I, Jansen van Rensburg PJ, Claassens S (2018) Bacillus-based bionematicides: development, modes of action and commercialisation. Biocontrol Sci Techn 28:629-653. https://doi.org/10.1080/09583157.2018. 1469000

Guo S, Liu M, Peng D, Ji S, Wang P, Yu Z, Sun M (2008) New strategy for isolating novel nematicidal crystal protein genes from Bacillus thuringiensis strain YBT1518. Appl Environ Microbiol 74:6997-7001. https://doi.org/10.1128/aem. 01346-08

Huang T et al (2018) Nematicidal activity of Cry1Ea11 from Bacillus thuringiensis BRC-XQ12 against the pine wood nematode (Bursaphelenchus xylophilus). Phytopathology 108:44-51. https://doi.org/10.1094/PHYTO-05-17-0179-R

latsenko I, Boichenko I, Sommer RJ (2014) Bacillus thuringiensis DB27 produces two novel protoxins, Cry21Fa1 and Cry21Ha1, which act synergistically 
against nematodes. Appl Environ Microbiol 80:3266-3275. https://doi.org/10. 1128/AEM.00464-14

Jones JT et al (2013) Top 10 plant-parasitic nematodes in molecular plant pathology. Mol Plant Pathol 14:946-961. https://doi.org/10.1111/mpp.12057

Koppenhöfer AM, Campbell JF, Kaya HK, Gaugler R (1998) Estimation of entomopathogenic nematode population density in soil by correlation between bait insect mortality and nematode penetration. Fundamental and Applied Nematology 21:95-102

Laemmli UK (1970) Cleavage of structural proteins during the assembly of the head of Bacteriophage T4. Nature:227. https://doi.org/10.1038/227680a0

Laznik Ž, Vidrih M, Trdan S (2012) The effect of different entomopathogens on white grubs (Coleoptera: Scarabaeidae) in an organic hayproducing grassland Archives of Biological Sciences 64:1235-1246.

Mohammed S, El Saedy MA, Enan MR, Ibrahim NE, Ghareeb A, Moustafa SA (2008) Biocontrol efficiency of Bacillus thuringiensis toxins against root-knot nematode, Meloidogyne incognita. J Mol Cell Biol 7:57-66

Orion D, Wergin W, Chitwood D, Erbe E (1994) Low-temperature scanning electron microscope observations of the Meloidogyne incognita egg mass: the gelatinous matrix and embryo development. J nematol 26:402

Peng D, Chai L, Wang F, Zhang F, Ruan L, Sun M (2011) Synergistic activity between Bacillus thuringiensis Cry6Aa and Cry55Aa toxins against Meloidogyne incognita. Microbial biotechnology 4:794-798

Pocurull M et al. (2020) Commercial formulates of Trichoderma induce systemic plant resistance to Meloidogyne incognita in tomato and the effect is additive to that of the Mi-1.2 resistance gene Front Microbiol 10:3042-3042 doi: https://doi.org/10.3389/fmicb.2019.03042

Porcar M, Juárez-Pérez V (2003) PCR-based identification of Bacillus thuringiensis pesticidal crystal genes. FEMS Microbiol Rev 26:419-432. https://doi.org/10. 1111/j.1574-6976.2003.tb00624.x

Radwan MA, Farrag SAA, Abu-Elamayem MM, Ahmed NS (2012) Biological control of the root-knot nematode, Meloidogyne incognita on tomato using bioproducts of microbial origin. Appl. Soil Ecol 56:58-62. https://doi.org/10. 1016/j.apsoil.2012.02.008

Ramalakshmi A, Udayasuriyan V (2010) Diversity of Bacillus thuringiensis isolated from Western Ghats of Tamil Nadu State, India. Curr Microbiol 61:13-18. https://doi.org/10.1007/s00284-009-9569-6

Sambrook J, Russell DW (2001) Molecular cloning: a laboratory manual, vol v. 2. Cold Spring Harbor Laboratory Press

Schindler A (1961) A simple substitute for a Baermann funnel. Plant Dis. Reptr 45 : $747-748$

Siddiqui ZA, Futai K (2009) Biocontrol of Meloidogyne incognita on tomato using antagonistic fungi, plant-growth-promoting rhizobacteria and cattle manure. Pest Manag Sci 65:943-948. https://doi.org/10.1002/ps.1777

Wang Y, Mei L, Wu J, Zhang L (2012) Detection and characterisation of a Bacillus thuringiensis crystal protein with nematicidal activity against the pinewood nematode Bursaphelenchus xylophilus Biocontrol Sci Technol 22:1143-1153 doi:https://doi.org/10.1080/09583157.2012.714743

Wergin W, Orion D (1981) Scanning electron microscope study of the root-knot nematode (Meloidogyne incognita) on tomato root. J Nematol 13:358

Yu Z et al (2015) The diverse nematicidal properties and biocontrol efficacy of Bacillus thuringiensis Cry6 A against the root-knot nematode Meloidogyne hapla. J Invertebr Pathol 125:73-80. https://doi.org/10.1016/j.jip.2014.12.011

Zuckerman BM, Dicklow MB, Acosta N (1993) A strain of Bacillus thuringiensis for the control of plant-parasitic nematodes Biocontrol Sci Techn 3:41-46 doi: https://doi.org/10.1080/09583159309355257

\section{Publisher's Note}

Springer Nature remains neutral with regard to jurisdictional claims in published maps and institutional affiliations.

\section{Submit your manuscript to a SpringerOpen ${ }^{\circ}$ journal and benefit from:}

- Convenient online submission

- Rigorous peer review

- Open access: articles freely available online

- High visibility within the field

- Retaining the copyright to your article

Submit your next manuscript at $\boldsymbol{\nabla}$ springeropen.com 